\title{
Financial Statements Analysis of Tanah Datar District Government
}

\author{
Wiwik Andriani ${ }^{1}{ }^{1 *}$, Roni Putra $^{2}$, Desi Handayani ${ }^{1}$, Dini Marisa ${ }^{1}$ \\ ${ }^{1}$ Accounting Department, ${ }^{2}$ Information Technology Department \\ Politeknik Negeri Padang \\ Padang, Indonesia \\ *wiwikandrianipnp@gmail.com, m.putra@gmail.com,ci_e@yahoo.com,dinimarisa6@gmail.com
}

\begin{abstract}
Transparent and accountable financial management on local government are demands and wants for all concerned. By carrying out a good financial management, the performance of local government would be increased. This research aims to analyze the financial performance of Tanah Datar District Government. The performance was measured by using five ratio which are relatively often used; on ratio of decentralization degree, ratio of local financial dependency, ratio of local financial independency, ratio of effectiveness on local own-source revenue, and ratio of effectiveness on local taxes. This research is descriptive qualitative using secondary data in the form of budget realization of Tanah Datar District Government in the year of 2016-2019. The findings show that the effective value for ratio of effectiveness on local own-source revenue, and ratio of effectiveness on local taxes are above $100 \%$. How ever, for the ratio of decentralization degree, ratio of local financial dependency, and ratio of local financial independency describe that this region is still regulated by the central and provincial government. It is clearly seen from the transfer revenue from central government which remains dominant within its local revenue in running the government.
\end{abstract}

Keywords-regional financial performance, ratio of decentralization degree, ratio of local financial dependency, ratio of local financial independency, ratio of effectiveness on local ownsource revenue, ratio of effectiveness on local taxes

\section{INTRODUCTION}

In establishing good governance, Indonesian government keeps performing varied activities in order to improve the transparancy and accountability on government' financial statements. In order to improve these transparancy and accountability in financial management, government implements a standard on accounting policy development by providing main guidelines in arrangement and presentation of the report for both central and local governments. A good quality report should meet the requirements set, and is presented comprehensively and audited independently. Meanwhile, Ikatan Akuntan Indonesia [1] stated that financial statements has four main qualitative characteristics, namely: understandable, relevant, reliable, and comparable.
As a matter of fact, financial statement has a role to provide relevant information regarding to financial and transactional positition carried out by a statements entity in one reporting periode, as highlihted in [2, p. 20]. In line with this, local government financial statement functions as a decision-making policy, thus the statement should be made in a simpler way to make it easy to be understood. Even though the statement is general purposive where the content is more general and simple in order to meet the satisfaction from all parties, in reality not all financial statements readers comprehend the statements comprehensively. Therefore, the inability in understanding and interpreting the financial statements should be assisted with the analysis of these statements.

Basically, the analysis of financial statements is an analysis conducted on various information presented in the statements. The difference between business and public sector financial statements is on the object itself. The use of financial ratio analysis on public sector has not widely been carried out, so theoritically the agreement on name and its measuring policy has yet established [3],[4, p. 231]. Munawir [5] stressed that ratio is a connection or balance between one certain total number with another total number. Nevertheless, in accordance with transparancy and accountabilty in local government financial management, financial ratio analysis on this local government financial statement should be performed. Tanah Datar Regency is one of the regencies in West Sumatera Province receiving a national level achievement; Unqualified Audit Opinion (WTP), for eight years in a row on their local government financial statements (LKPD) from year 2012 to 2019. Therefore, to facilitate the local governments and the users of financial statements in analyzing the financial statements, the researchers are determined to conduct a research related to the analysis of financial statement of Tanah Datar government in assessing their performances.

\section{RESEARCH METHODS}

This research applied descriptive quantitative approach. Descriptive study was designed to collect the data in describing the charachteristics of a person, occasion, or situation $[6, \mathrm{p}$. 90]. The main data source for this research was secondary data. 
Ghozali [6, p. 94] stated that in conducting a research, secondary data was information which was gathered by others excluded the researchers. Notably, the secondary data in this research was perceived from the budget realization statement of Tanah Datar Local Government from year 2016 to 2019.

\section{RESULTS AND DISCUSSION}

Harahap [7] highlighted that the analysis of financial statement means "breaking down of certain accounts on financial statements becoming smaller information unit, and looking at significant relationship or viewing it as a very important and informative among each unit for both quantitative and non-quantitative data. The purpose was to ascertain in-depth financial condition which was necessary in making right decision [8]. Ulum [9, p. 30] pointed out that financial analysis is an effort in identifying the financial characteristics based on available financial statements. Several ratio analysis were used in this research as seen below:

\section{A. Ratio of Decentralization Degree}

The degree of decentralization was counted based on the comparison between the amount of Local Own-Source Revenue (PAD) and the amount of regional revenue. The ratio showed the degree of PAD contribution toward the total amount of regional revenue. The higher the contribution, the more the capability of local governemnt in performing the decentralization [10, p. 140]. The ratio is formulated as follow (See in Table 1):

$$
\begin{aligned}
& \text { Ratio of Decentralization Degree }=\frac{\text { Local Own Source Revenue }}{\text { Total of Regional Revenue }} \times 100 \% \\
& \text { Source: [10, p. 140] }
\end{aligned}
$$

TABLE I. DEgREe of AsSESSMENT DeCENTRALIZATION

\begin{tabular}{|l|l|l|}
\hline No & \multicolumn{1}{|c|}{ Percentage } & \multicolumn{1}{|c|}{ Category } \\
\hline 1 & $0 \%-10 \%$ & Deficient \\
\hline 2 & $10 \%-20 \%$ & Less \\
\hline 3 & $20 \%-30 \%$ & Enough \\
\hline 4 & $30 \%-40 \%$ & Moderate \\
\hline 5 & $40 \%-50 \%$ & Good \\
\hline 6 & $>50 \%$ & Excellent \\
\hline \multicolumn{2}{|c|}{ Source: [11]. }
\end{tabular}

TABLE II. RATIO OF DECENTRALIZATION DEgREE OF TANAH DATAR REGENCY

\begin{tabular}{|l|l|l|l|l|}
\hline Year & $\begin{array}{c}\text { Total of } \\
\text { PAD }\end{array}$ & Total of PD & $\begin{array}{c}\text { Decentra } \\
\text { lization }\end{array}$ & $\begin{array}{c}\text { Degree of } \\
\text { Decentralization }\end{array}$ \\
\hline 2016 & $\begin{array}{l}\mathrm{Rp} \\
118.971 .143\end{array}$ & $\begin{array}{l}\mathrm{Rp} \\
1.188 .763 .795\end{array}$ & $10,01 \%$ & Less \\
\hline 2017 & $\begin{array}{l}\mathrm{Rp} \\
172.812 .023\end{array}$ & $\begin{array}{l}\mathrm{Rp} \\
1.343 .221 .487\end{array}$ & $12,87 \%$ & Less \\
\hline \multirow{2}{*}{2018} & $\begin{array}{l}\mathrm{Rp} \\
115.914 .188\end{array}$ & $\begin{array}{l}\mathrm{Rp} \\
1.230 .335 .932\end{array}$ & $9,42 \%$ & Deficient \\
\hline 2019 & $\begin{array}{l}\mathrm{Rp} \\
129.785 .828\end{array}$ & $\begin{array}{l}\mathrm{Rp} \\
1.339 .707 .228\end{array}$ & $9,69 \%$ & Deficient \\
\hline & $\begin{array}{l}\mathrm{Rp} \\
134.370 .795\end{array}$ & $\begin{array}{l}\mathrm{Rp} \\
1.275 .507 .110\end{array}$ & $10,50 \%$ & Less \\
\hline
\end{tabular}

Source: BPS West Sumatera and LRA Regency of Tanah Datar (processed data).
Based on Table 2, the result of ratio measurement above from year 2016 to 2019, it can be concluded that the degree of decentralization of Tanah Datar Regency is on "less" category with the average score of $10.50 \%$. It means that the involvement of central government in regional development is still higher

\section{B. Ratio of Local Financial Dependency}

The ratio of local financial dependency was measured by comparing the amount of transfer revenue received by the regional revenue with the total local government revenue. The higher the ration, the bigger the dependency of local government to central/ provincial government. The ratio is formulated as follow (See in Table 3):

$$
\text { Ratio of Local Financial Dependency }=\frac{\text { Transfer Revenue }}{\text { Total of Regional Revenue }} \times 100 \%
$$

TABLE III. THE ASSESSMENT CRITERIA FOR LOCAL GOVERNMENT DEPENDENCY

\begin{tabular}{|l|l|l|}
\hline No & \multicolumn{1}{|c|}{ Percentage } & \multicolumn{1}{|c|}{ Category } \\
\hline 1 & $0 \%-10 \%$ & Very Low \\
\hline 2 & $10 \%-20 \%$ & Low \\
\hline 3 & $20 \%-30 \%$ & Medium \\
\hline 4 & $30 \%-40 \%$ & Sufficient \\
\hline 5 & $40 \%-50 \%$ & High \\
\hline 6 & $>50 \%$ & Very High Source $:[11]$. \\
\hline
\end{tabular}

TABLE IV. THE DEPENDENCY OF LOCAL FINANCIAL OF TANAH DATAR REGENCY

\begin{tabular}{|l|l|l|l|l|}
\hline Year & \multicolumn{1}{|c|}{$\begin{array}{c}\text { Total of } \\
\text { Local } \\
\text { Revenue }\end{array}$} & $\begin{array}{c}\text { Government } \\
\text { Revenue }\end{array}$ & $\begin{array}{c}\text { Ratio of } \\
\text { Dependency }\end{array}$ & $\begin{array}{c}\text { Level of } \\
\text { Dependency }\end{array}$ \\
\hline 2016 & $\begin{array}{l}\mathrm{Rp} \\
963.487 .573\end{array}$ & $\begin{array}{l}\mathrm{Rp} \\
1.188 .763 .795\end{array}$ & $81,05 \%$ & Very high \\
\hline 2017 & $\begin{array}{l}\mathrm{Rp} \\
928.980 .499\end{array}$ & $\begin{array}{l}\mathrm{Rp} \\
1.343 .221 .487\end{array}$ & $69,16 \%$ & Very high \\
\hline 2018 & $\begin{array}{l}\mathrm{Rp} \\
944.906 .738\end{array}$ & $\begin{array}{l}\mathrm{Rp} \\
1.230 .335 .932\end{array}$ & $76.80 \%$ & Very high \\
\hline & $\mathrm{Rp}$ & $\mathrm{Rp}$ & & \\
\hline 2019 & 984.486 .247 & 1.339 .707 .228 & $73,49 \%$ & Very high \\
\hline & $\mathrm{Rp}$ & $\mathrm{Rp}$ & & \\
& 955.465 .264 & 1.275 .507 .110 & $75,12 \%$ & \\
\hline
\end{tabular}

Source: BPS West Sumatera and LRA Regency of Tanah Datar (processed data).

Table 4 above shows that the dependency level of transfer revenue is very high, seen from the average score which is $75.12 \%$. It can be said that this region still has a high dependency on central government in running the government. Notably, the conducted analysis can be a valuable input for the regency in increasing its revenue by exploring its potential resource. 


\section{Ratio of Local Financial Independency}

The independency ratio of local financial was measured by comparing the amount of local own-source revenue divided by the amount of transfer revenue received from central and provincial governement and regional loan. The higher the number of the ratio, the higher the financial independency of the local government. The ratio is formulated as follow (See in Table 5):

$$
\begin{aligned}
& \text { Ratio of Local Financiallindependency }
\end{aligned}
$$

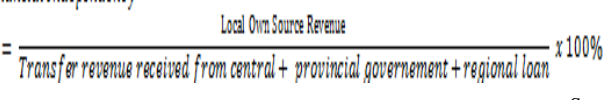

TABLE V. THE RELATIONSHIP PATTERN OF LOCAL GOVERNMENT ABILITY

\begin{tabular}{|l|l|l|}
\hline $\begin{array}{c}\text { Financial } \\
\text { Ability }\end{array}$ & \multicolumn{1}{c|}{$\begin{array}{c}\text { Independency } \\
(\boldsymbol{\%})\end{array}$} & $\begin{array}{c}\text { Relationship } \\
\text { Pattern }\end{array}$ \\
\hline Very Low & $0 \%-25 \%$ & Instructive \\
\hline Low & $25 \%-50 \%$ & Consultative \\
\hline Medium & $50 \%-75 \%$ & Participative \\
\hline High & $75 \%-100 \%$ & Delegative \\
\hline
\end{tabular}

- The instructive relationship pattern. It is when the role of central government is more dominant rather than the independency of local government (the region which incapable in performing regional autonomy).

- The consultative relationship pattern. It is when the involvement of central government has been lessen because the local government is considered to have a little bit ability to run the regional autonomy affairs.

- The participative relationship pattern. It is when the involvement of central government has been lessen due to the local government independency level has approached the ability to run the regional autonomy affairs.

- The delegative relationship pattern. It is the absence of central government involvement as the local government is considered totally able and independent in running its regional autonomy affairs.

TABLE VI. RATIO OF LOCAL FINANCIAL INDEPENDENCY OF TANAH DATAR REGENCY

\begin{tabular}{|l|l|l|l|l|}
\hline Year & Total of PAD & $\begin{array}{c}\text { Balance/ } \\
\text { Transfer Fund }\end{array}$ & $\begin{array}{c}\text { Independency } \\
\text { Ratio }\end{array}$ & $\begin{array}{c}\text { Dependency } \\
\text { Ratio }\end{array}$ \\
\hline 2016 & $\begin{array}{l}\mathrm{Rp} \\
118.971 .143\end{array}$ & $\begin{array}{l}\mathrm{Rp} \\
1.056 .977 .283\end{array}$ & $11,26 \%$ & Very low \\
\hline 2017 & $\begin{array}{l}\mathrm{Rp} \\
172.812 .023\end{array}$ & $\begin{array}{l}\mathrm{Rp} \\
1.041 .225 .557\end{array}$ & $16,60 \%$ & Very low \\
\hline 2018 & $\begin{array}{l}\mathrm{Rp} \\
115.914 .188\end{array}$ & $\mathrm{Rp} 987.211 .384$ & $11,74 \%$ & Very low \\
\hline 2019 & $\begin{array}{l}\mathrm{Rp} \\
129.785 .828\end{array}$ & $\begin{array}{l}\mathrm{Rp} \\
1.157 .151 .619\end{array}$ & $11,22 \%$ & Very low \\
\hline & $\begin{array}{l}\mathrm{Rp} \\
134.370 .795\end{array}$ & $\begin{array}{l}\mathrm{Rp} \\
1.060 .641 .460\end{array}$ & $12,70 \%$ & \\
\hline
\end{tabular}

Source: BPS West Sumatera and LRA Regency of Tanah Datar (processed data).
Table 6 above shows that the ratio measurement of financial independency of Tanah Datar Regency is still in instructive level. It means that the role of central government is more dominant in the local government independency. It indicates that the local government is still dependend on the aids from central and provincial government.

\section{Ratio of Effectiveness on Local Own-Source Revenue}

The ratio of PAD effectiveness was measured by comparing the realisation of PAD revenue with the target of $\mathrm{PAD}$ revenue (buggetted). The ratio is formulated as follow:

$$
\text { Ratio of Effectiveness on Local Own Source Revenus }=\frac{\text { Realisation of PAD Revenus }}{\text { Target of PAD Revenue }} \times 100 \%
$$

Source : [10, p. 140]

The PAD effectiveness ratio describes the ability of the local government in mobilizing PAD revenue in accordance with the targetted one. Generally, the value of PAD effectiveness can be categorized as below:

- Very effective : $>100 \%$

- Effective

$: 100 \%$

- Quite effective

: 90\%-99\%

- Less effective

: $75 \%-89 \%$

- Ineffective $:<75 \%$

TABLE VII. RATIO OF PAD EFFECTIVENESS OF TANAH DATAR REGENCY

\begin{tabular}{|c|l|l|l|l|}
\hline Year & PAD Realization & $\begin{array}{l}\text { Target of PAD } \\
\text { Revenue }\end{array}$ & $\begin{array}{c}\text { Ratio of } \\
\text { Effectiveness }\end{array}$ & $\begin{array}{l}\text { Value of } \\
\text { Effectiveness }\end{array}$ \\
\hline 2016 & Rp 118.971.143 & Rp 115.232.849 & $103,24 \%$ & $\begin{array}{l}\text { Very } \\
\text { Effective }\end{array}$ \\
\hline 2017 & Rp 172.812.023 & Rp. 128.397 .031 & $134,59 \%$ & $\begin{array}{l}\text { Very } \\
\text { Effective }\end{array}$ \\
\hline 2018 & Rp 11.914.188 & $\begin{array}{l}\text { Rp. } \\
152.110 .032\end{array}$ & $76,20 \%$ & $\begin{array}{l}\text { Very } \\
\text { Effective }\end{array}$ \\
\hline 2019 & Rp 129.785.828 & $\begin{array}{l}\text { Rp. } \\
146.175 .319\end{array}$ & $88,79 \%$ & $\begin{array}{l}\text { Very } \\
\text { Effective }\end{array}$ \\
\hline & Rp.134.370.795 & $\begin{array}{l}\text { Rp. } \\
135.478 .807\end{array}$ & $100,71 \%$ & \\
\hline
\end{tabular}

Source: BPS West Sumatera and LRA Regency of Tanah Datar (processed data).

Table 7 above presents that this regency can surpass the target set, and it reaches the high number even though there is a variation on it. In general, it can be concluded that since the last four years, the PAD effectiveness ratio of Tanah Datar has been effective. It is in line with the measurement criteria of PAD effectiveness level which places Tanah Datar with the average score of $100.71 \%$.

\section{E. Ratio of Effectiveness on Local Taxes}

Apart from the analysis of effectiveness ratio and PAD efficiency, effectiveness analysis and local taxes efficiency was also carried out.

$$
\text { Ratio of Effectiveness on Local Taxes }=\frac{\text { Realisation of Local Taxes Revenue }}{\text { Target of Local Taxes Revenue }} \times 100 \%
$$


Effectiveness ratio of local taxes shows the ability of local government in collecting local taxes correspondingly with the number of targetted local taxes revenue. This type of ratio was recognized good if only the ratio reached the minimum number of 1 or $100 \%$.

TABLE VIII. The MEASUREMENT OF EFFECTIVENESS RATIO ON TANAH DATAR REGENCY

\begin{tabular}{|l|l|l|l|l|}
\hline Year & $\begin{array}{c}\text { Local } \\
\text { Taxes } \\
\text { Realization }\end{array}$ & $\begin{array}{c}\text { Targetted } \\
\text { Local } \\
\text { Taxes } \\
\text { Revenue }\end{array}$ & $\begin{array}{c}\text { Efficiency } \\
\text { Ratio }\end{array}$ & $\begin{array}{l}\text { Effectiveness } \\
\text { Value }\end{array}$ \\
\hline 2016 & $\begin{array}{l}\mathrm{Rp} \\
11.771 .072\end{array}$ & $\begin{array}{l}\mathrm{Rp} \\
11.946 .601\end{array}$ & $98,53 \%$ & Effective \\
\hline 2017 & $\begin{array}{l}\mathrm{Rp} \\
16.523 .395\end{array}$ & $\begin{array}{l}\mathrm{Rp} \\
12.932 .920\end{array}$ & $127,76 \%$ & $\begin{array}{l}\text { Very } \\
\text { effective }\end{array}$ \\
\hline 2018 & $\begin{array}{l}\mathrm{Rp} \\
19.847 .312\end{array}$ & $\begin{array}{l}\mathrm{Rp} \\
17.894 .893\end{array}$ & $110,91 \%$ & $\begin{array}{l}\text { Very } \\
\text { effective }\end{array}$ \\
\hline 2019 & $\begin{array}{l}\mathrm{Rp} \\
19.578 .257\end{array}$ & $\begin{array}{l}\mathrm{Rp} \\
22.615 .342\end{array}$ & $86,57 \%$ & $\begin{array}{l}\text { Less } \\
\text { effective }\end{array}$ \\
\hline & $\begin{array}{l}\mathrm{Rp} \\
16.930 .009\end{array}$ & $\begin{array}{l}\mathrm{Rp} \\
16.347 .439\end{array}$ & $105.94 \%$ & \\
\hline
\end{tabular}

Source: BPS West Sumatera and LRA Regency of Tanah Datar (processed data).

Significantly, table 8 above illustrates the effectiveness ratio of local taxes which is in effective value, seen from the obtained average score of $105.94 \%$. It means that this regency has been effective in its local taxes realization as it can surpass its target even though the number is varied. Taken from the number above, there are more potentials which can be developed in order to increase the local government taxes.

\section{CONCLUSION}

The result of the analysis shows that this research concerns on the financial performance of Tanah Datar Regency in the year of 2016-2019 based on ratio of decentralization degree, ratio of local financial dependency, ratio of local financial independency, ratio of effectiveness on local own-source revenue, and ratio of effectiveness on local taxes.

The measurement results are varied in number where the effectiveness on local own-source revenue and the effectiveness on local taxes have the average value above $100 \%$, and categorized effective. On the other hand, ratio of decentralization and ratio of dependency are still subjected to central and provincial government. Overall, the development of local potential should be increased in order to establish the independency and as well to reduce the dependency to central and provincial government. It is in agreement with the aim of local autonomy.

\section{REFERENCES}

[1] I.A. Indonesia, Standar Akuntansi Keuangan. Jakarta: Salemba Empat, 2008 .

[2] Standar Akuntansi Pemerintahan, 2005.

[3] W. Widodo, Analisa Rasio Keuangan Daerah dalam Menghadapi Otonomi Daerah, Manajemen Keuangan Daerah. Yogyakarta: UPP YKPN, 2001

[4] A. Halim, Akuntansi Keuangan Daerah. Jakarta: Salemba Empat, 2004.

[5] S. Munawir, Analisis Laporan Keuangan, Edisi IV. Yogyakarta: Liberty, 2004 .

[6] I. Ghozali, Aplikasi Analisis Multivariate Dengan Program SPSS. Semarang: Badan Penerbit Universitas Diponegoro, 2016.

[7] S. Harahap, Analisis Kritis Laporan Keuangan, Edisi 1-5. Jakarta: PT. Raj Garfindo Persada, 2006.

[8] M. Mahsun, Pengukuran Kinerja Sektor Publik. Yogyakarta: BPFE Yogyakarta, 2006

[9] I. Ulum, Audit Sektor Publik. Jakarta: Bumi Aksara, 2012.

[10] M. Mahmudi, Analisis Laporan Keuangan Pemerintah Daerah. Yogyakarta: UPP TSIM YKPN, 2019.

[11] N. Sartika and A.I. Pratama, "Analisis Rasio Keuangan Dalam Menila Kinerja Keuangan Pemerintah Kabupaten Siak Tahun Anggaran 2012 2016," Moneter, vol. 6, no. 2, pp. 179-188, 2019. 